\title{
Application of Three-Dimensional Printing in Facial Plastic and Reconstructive Surgery
}

\author{
Dong-Kyu Kim ${ }^{1,2}$ and Chan Hum Park ${ }^{1,2}$ \\ ${ }^{1}$ Department of Otorhinolaryngology-Head Neck Surgery, Chuncheon Sacred Heart Hospital, Hallym University College of Medicine, \\ Chuncheon; and ${ }^{2}$ Nano-Bio Regenerative Medical Institute, Hallym University, Chuncheon, Korea
}

\section{안면 성형 및 재건 수술에서 3차원 프린터의 활용}

\author{
김 동 규 $^{1,2} \cdot$ 박 찬 흠 ${ }^{1,2}$ \\ 한림대학교 의과대학 춘천성심병원 이비인후-두경부외과학교실, ${ }^{1}$ 한림대학교 나노바이오재생의학연구소 ${ }^{2}$
}

\author{
Received March 9, 2015 \\ Accepted March 28, 2015 \\ Address for correspondence \\ Dong-Kyu Kim, MD \\ Department of Otorhinolaryngology- \\ Head Neck Surgery, \\ Chuncheon Sacred Heart Hospital, \\ Hallym University \\ College of Medicine, \\ 77 Sakju-ro, Chuncheon 24253, \\ Korea \\ Tel $+82-33-240-5181$ \\ Fax $+82-33-241-2909$ \\ E-mail doctordk@naver.com
}

Recently, three-dimensional (3D) printing technology can produce any 3D shape of solid scaffolding that can be designed by digital image. Thus, there are many potential patient-specific applications for 3D printing in medicine, including facial plastic and reconstructive surgery, which could have a significant impact in changing the ways patients are treated for various conditions in the future. To date, individually printed metal implants and synthetic devices are currently being used on limited cases in various medical fields, including facial plastic and reconstructive surgery. Herein we describe concepts and characteristics of 3D printing technology and its clinical applications in facial plastic and reconstructive surgery.

Korean J Otorhinolaryngol-Head Neck Surg 2015;58(9):599-603

Key Words Plastic - Printing - Reconstructive surgical procedures $\cdot$ Regenerative medicine $\cdot$ Surgery $\cdot$ Three-dimensional $\cdot$ Tissue engineering.

\section{서 론}

1984년에 three-dimensional(3D) 프린터가 처음 개발되고 1986년에 처음으로 금속 3D 프린터 특허가 출원된 이후 오늘 날 $3 \mathrm{D}$ 프린팅 기술은 3차원의 입체물을 만들어 내는 기술로 제조업 분야에서 전 세계적으로 가장 각광받고 있는 기술 중 하나이다. 최근 발표된 보고에 따르면, $3 \mathrm{D}$ 프린팅 기술은 12 가지 잠재적 경제 혁신기술 중 하나로 전 세계적으로 2025년 까지 매년 2300억 달러에서 5500억 달러의 경제적 효과가 예 상되며(McKinsey 2013), 특히 보건의료 분야의 경우 3D 프 린팅 기술 점유율이 $15.1 \%$ 로 소비재, 자동차 분야에 이어 세 번째에 해당되며(Whohlers Associate 2012), 향후 5년 내에 자동차 분야를 추월할 것으로 예상된다. ${ }^{1)}$

제조업에서 주로 사용되는 생산 방식은 절삭가공 방식(subtractive manufacturing)으로 큰 입체의 원재료를 기계가공
혹은 레이저를 이용하여 자르거나 다듬는 방법이다. 반면에, $3 \mathrm{D}$ 프린팅 방식은 고체, 액체, 혹은 분말 형태의 소재를 설계 데이터에 따라서 $3 \mathrm{D}$ 프린터를 통해 적층 방식(layer by layer) 으로 쌓아 올려 입체물을 제조하는 생산 방식(적층가공 방식, additive manufacturing)이다.2) 이러한 생산 방식의 차이가 의 미하는 바는 절삭가공 방식의 경우 원재료의 상당수가 버려 지는 문제점이 있으나, $3 \mathrm{D}$ 프린팅은 필요한 만큼의 원재료만 이용함으로 원재료 절감이 가능하다는 측면과 기존의 절삭 가공 방식이 소품종 대량생산 구조에 용이하였던 것에 비해 $3 \mathrm{D}$ 프린팅은 다품종 소량생산 구조에 최적화되어 있는 제조 방식이라는 점이다. 그러므로, $3 \mathrm{D}$ 프린팅은 개인 맞춤의료 및 의료비용 절감이 주요 화두인 의료 분야에서 특히 활용도가 높은 기술이다. ${ }^{1-3)}$

대표적인 3D 프린팅 방식으로는 고체기반의 fused deposition modeling(FDM), 액체기반의 stereolithography(SLA), 
그리고 분말기반의 selective laser sintering(SLS) 등이 있으 며, 액체 형태의 photopolymer 원료를 노즐을 통해 순간적 으로 고온 히팅하여 이를 경화시켜 형상을 제작하는 미국 3D Systems의 SLA 방식이 가장 널리 사용되고 있다. 오늘날, 의 료 분야의 $3 \mathrm{D}$ 프린팅 기술 적용은 맞춤형 보청기, 치아 보철 물, 의수 및 의족 등에서 주로 이루어지고 있으며, 기도기관지 연화증(tracheobronchomalacia) 신생아에서 3D 프린터를 활용하여 성공적으로 기도 재건에 성공한 사례 등ㄴ) 특수한 상 황에서의 $3 \mathrm{D}$ 프린터를 이용하는 사례가 증가하고 있다.

그러므로, 본 종설에서는 $3 \mathrm{D}$ 프린터의 개념과 활용도를 살 펴보고, 나아가 안면 성형 및 재건 분야에서 활용 가능한 $3 \mathrm{D}$ 프린팅 기술의 연구성과에 대해 고찰해보고자 한다.

\section{D 프린터 개념}

3D 프린터는 computer aided design을 이용하여 생산하고 자 하는 형상을 3 차원 설계 데이터로 만들고 재료를 가공. 적층 방식으로 쌓아 올려 입체물을 제조하는 장비로서, 레이 저와 파우더 재료를 활용하여 신속 조형하는 기술을 의미하 는 rapid prototyping에서 유래하였다. 따라서, 3D 프린터는 적층 방식과 입체물 제조에 활용 가능한 재료에 따라 다양한 기술로 구분할 수 있으며, 적층 방식은 압출(extrusion), 잉크젯
방식의 분사(jetting), 광경화(light polymerized), 분말 소결 (glranular sintering), 레이저 가열 증착 조형(laser-aided direct metal tooling), 인발(wire), 시트 접합(sheet lamination) 등으로 구분 가능하며(Table 1), 활용 가능 재료는 폴리머(polymer), 금속, 종이(film), 왁스, 아크릴 등 매우 다양하다. 대 표적인 $3 \mathrm{D}$ 프린팅 기술별 특징과 장단점을 살펴보면(Table 2), 우선 압출 적층 방식을 활용한 $\mathrm{FDM}$ 기술은 가는 필라멘 트(실) 형태의 열가소성 물질을 노즐 안에서 녹여 얇은 필름 형태로 출력하는 방식으로 적층하며, 타 방식에 비해 장치 구조와 프로그램이 간단하여 가격과 유지보수 비용이 낮고, 다양한 소재에 적용이 가능함과 동시에 단순한 구조로 대형 화에 용이한 장점을 지닌다. 그러나 제작 속도가 느리고 세부 형상 구현이 미흡한 것이 단점이다. 분사 방식을 활용한 기술 로는 대표적으로 multi jetting modeling이 있으며 이는 프린 터 헤드에서 광경화성 수지와 왁스(wax)를 동시에 분사하고 자외선으로 고형화하는 방식으로 적층한다. 이는 정밀도가 가장 높은 기술이며, 광경화성 수지의 특성상 투명한 조형물 제작이 가능하다. 다만, 강도가 약하며 $65^{\circ} \mathrm{C}$ 이상의 온도에서 변형이 나타날 수 있다. 광경화 방식은 대표적으로 SLA가 있 으며, 이는 액체 광경화성 수지에 UV 레이저를 조사하여 경화 시키는 방식으로 적층하며, 조형하고자 하는 모델의 아랫부분 부터 경화되어 적층되는 방식이다. 중간 정도의 조형 속도로 가

Table 1. 3D 프린팅 기술의 적층 방식

\begin{tabular}{ll}
\hline \multicolumn{1}{c}{ 적층 방식 } & 3D 프린팅 기술의 특징 \\
\hline Extrusion & 고온으로 가열한 재료를 강한 압력을 가해서 구멍으로부터 압출하여 성형하는 방식 \\
Jetting & 고압의 액체 원료를 분출시키는 방식 \\
Light polymerized & 빛의 조사에 의해 광경화성 플라스틱에서 일어나는 중합반응을 이용하여 재료를 고형화하는 방식 \\
Granular sintering & 재료를 융점 이하로 가열하여 고형화하는 방식 \\
Directed energy deposition & 레이저 등의 에너지원을 활용하여 재료를 완전히 녹여서 기존의 구조물 및 손상 부품에 적층하는 방식 \\
Wire & 끝이 좁은 다이스를 통해 생성된 실형태의 폴리머 재료를 이용해서 이를 조형물 적층에 활용하는 방식 \\
Sheet lamination & 얇은 필름 모양의 재료를 접착제를 사용하거나 열 접착방법으로 접착시키는 방식
\end{tabular}

Table 2. 대표적인 3D 프린팅 기술의 분류 및 특징

\begin{tabular}{|c|c|c|}
\hline 3D 프린팅 조형 방식 & 소재 & 특징 \\
\hline $\begin{array}{l}\text { 압출 적층 조형 } \\
\text { (fused deposition modeling) }\end{array}$ & $\begin{array}{l}\text { Thermoplastics, } \\
\text { eutectic metals }\end{array}$ & $\begin{array}{l}\text { 열가소성 고체수지 재료를 노즐 안에서 녹여 얇은 필름형태로 출력하여 } \\
\text { 쌓아 만드는 방식, 제작 비용과 시간 면에서 효율적 }\end{array}$ \\
\hline $\begin{array}{l}\text { 광경화수지 조형 } \\
\text { (stereo lithography) }\end{array}$ & Photopolymer & $\begin{array}{l}\text { 액체 광경화성 폴리머에 레이저를 선택적으로 방출하여 경화시키는 방식, } \\
\text { 얇고 미세한 형상 제작 }\end{array}$ \\
\hline $\begin{array}{l}\text { 선택적 레이저 소결 조형 } \\
\text { (selective laser sintering) }\end{array}$ & $\begin{array}{l}\text { Thermoplastic, } \\
\text { metals powders, } \\
\text { ceramic powders }\end{array}$ & $\begin{array}{l}\text { 도포된 분말에 선택적으로 레이저를 조사, 가열하고 분말을 도포하는 } \\
\text { 과정을 반복하여 적층시키는 방식, 높은 정밀성 가짐 }\end{array}$ \\
\hline $\begin{array}{l}\text { 직접 금속 레이저 소결 조형 } \\
\text { (direct metal laser sintering) }\end{array}$ & Almost any alloy metal & $\begin{array}{l}\text { 도포된 금속 파우더에 선택적으로 레이저를 조사시켜 용융시키는 방식으로 } \\
\text { 적층, 강도 높은 제품 제작에 사용함 }\end{array}$ \\
\hline 전자빔 소결(electron beam melting) & Titanium alloys & $\begin{array}{l}\text { 고진공 상태에서 전자빔을 통해 금속 파우더를 용해하는 방식으로 적층, } \\
\text { 티타늄 같은 고강도 금속 가공에 적합 }\end{array}$ \\
\hline $\begin{array}{l}\text { 적층물 제조 } \\
\text { (laminated object manufacturing) }\end{array}$ & Paper, foil, plastic film & $\begin{array}{l}\text { 종이, 플라스틱 같이 층으로 된 물질을 겹겹이 쌓아 만들며, 재료 물질이 } \\
\text { 가장 저렴함 }\end{array}$ \\
\hline
\end{tabular}


장 널리 쓰이는 기술이나 강도가 약하고 $60^{\circ} \mathrm{C}$ 이상의 온도에서 변형이 나타날 수 있는 단점을 지닌다. 고체 분말 소결을 활용 한 SLS 기술은 도포된 파우더 분말에 선택적으로 레이저를 조사하고 파우더 분말을 도포하는 공정을 반복하여 적층하 는 방식으로 조형속도가 빠르고 활용 가능한 재료가 광범위 한 장점을 지닌다. 다만, 다양한 원료 사용에 따른 가열온도 와 레이저 별수를 조절해야 하는 단점을 지닌다. 또 다른 기술 로 direct metal laser sintering이 있으며, 이는 도포된 금속 파우더 분말에 선택적으로 고출력 레이저를 조사하여 용융 시키는 방식으로 적층하며, SLS 기술과의 차이점은 금속 재 료에 국한되어 사용된다는 점이다. 그 밖에, 인발 방식을 이용 한 electron beam freeform fabrication 및 시트 접합을 이용 한 laminated object manufacturing 등이 있다.

\section{의료에서 $3 \mathrm{D}$ 프린터 활용}

체내 조직 및 장기는 개인별로 조금씩 서로 다른 형태를 지 니고 있기 때문에 보건의료 분야에서 $3 \mathrm{D}$ 프린팅 기술을 활 용하면 개인 맞춤형 의료를 실현할 수 있다. 오늘날, 맞춤형 의료를 위한 $3 \mathrm{D}$ 프린터의 대표적인 적용으로 맞춤형 보형물 (보청기, 치과용 재료, 의수, 의족 등) 제작이 있다. 예를 들어, 기존의 보청기 제작은 사람마다 귀 모양이 다르기 때문에 수 작업으로 ear molding을 진행해야 했으나, 3D 프린팅 기술을 이용한 맞춤형 보청기는 실리콘으로 귀 모양을 본뜬 후 $3 \mathrm{D}$ 스캐너를 이용하여 이를 정확하게 인식하고 이에 따라 $3 \mathrm{D}$ 프린터로 출력하는 방식이다. ${ }^{5)}$ 또한, 치아 보철물(크라운 혹은 브릿지)에 $3 \mathrm{D}$ 프린터를 이용해 효과적으로 제작할 수 있으며 기존에 치기공사에 의해 주조된 방식에 비해 일정한 고품질 의 치아 보철물을 짧은 시간에 만들 수 있는 장점을 지닌다. ${ }^{6}$ 이러한 맞춤형 보형물 외에도, 골절 수술이나 해부학적으로 구조가 복잡한 부위의 수술 전에 3D 프린터를 이용하여 수 술부위를 제작 후 시뮬레이션(simulation)을 통해 수술 시간 을 단축하고 보다 정교한 수술을 진행하여 수술 중 발생할 수 있는 2차적 손상을 최소화할 수 있다. ${ }^{7-12)}$

현재 $3 \mathrm{D}$ 프린터의 의료 분야의 활용은 이와 같은 단순한 개인 맞춤형 보형물이나 수술 전 시뮬레이션에 머물러 있으 나, 3D 프린팅 기술은 가까운 시일 내에 바이오프린팅(bioprinting)으로 발전할 것으로 생각된다. 바이오프린팅이란 살 아있는 세포를 원하는 형상 혹은 패턴으로 적층하여 체내 조 직이나 장기를 제작하는 것으로 조직공학 및 재생의학에서 그 활용도가 매우 높다. 다시 말해, 원하는 시기에 조직이나 장 기가 바이오프린팅으로 제작된다면 보관상의 문제뿐만 아니 라 장기 기증자를 기다려야 하는 불편이 해소될 것이다. ${ }^{13-15)}$

\section{안면 성형 및 재건 분야에서 $3 \mathrm{D}$ 프린터 활용}

오늘날 안면 성형 및 재건 분야에서 $3 \mathrm{D}$ 프린터는 악교정 수 술(orthognathic surgery), 외상 후 재건 수술(reconstructive post-traumatic surgery), 종양 수술 및 이식학(implantology) 등 다양한 임상적 상황에서 사용된다. ${ }^{16)}$ 최근 연구에 따르면, 하악골의 부분절제(segmental resection)가 예정인 환자에서 $3 \mathrm{D}$ 프린터를 이용하여 하악골을 형상화한 후 이를 이용하여 부분절제 후 재건을 위한 플레이트(plate)를 미리 디자인한 경 우, 고식적인 재건 방식보다 좋은 기능적, 미용적 재건 결과를 얻을 수 있었다고 보고하였다. ${ }^{1718)}$ 상악골(maxilla) 수술 시에 도 3D 프린터를 이용하여 미리 template를 만들어 Le Fort 절골술이나 골절편 전위술(repositioning)을 위한 수술 전 시뮬레이션으로 활용한 경우 보다 나은 수술 후 결과를 얻었 다는 보고도 있다. ${ }^{19)}$ 게다가, 하악각 절골술 후 관절융기 결손 (condylar detect)이 발생한 경우에 3D 프린터를 이용하여 nanoscale hydroxyapatite/polyamide 임플란트를 제작하여 성 공적 결손부위를 재건한 증례, ${ }^{20)} 3 \mathrm{D}$ 프린터로 티타늄 임플란 트를 제작하여 만족스러운 하악지(ramus of mandible) 재건 결과를 얻은 증례, ${ }^{21)}$ 6명의 환자에서 하악골 절골술 후 자가 장골 이식(autogenous iliac grafts)과 3D 프린터를 이용한 티 타늄 트레이(tray)를 동시에 사용하여 만족스러운 재건을 시 행한 보고도 있다.2) 이러한 술 전 시뮬레이션이나 임플란트 제작과 관련된 보고 이외에도 $3 \mathrm{D}$ 프린터를 이용하여 제작한 하악골 형상 지지체(scaffold)에서 골수 줄기세포(bone marrow stem cell)를 성공적으로 증식시킨 연구 결과,23) 레이저 를 이용한 고가의 제작 방식이 아닌 종이 필름을 기반으로 하 는 $3 \mathrm{D}$ 프린터를 개발하여 저비용으로 하악골 임플란트 제작 을 시도한 연구도 있다. ${ }^{16}$

또한, $3 \mathrm{D}$ 프린팅 기술을 이용하여 모형이 아닌 실제 소리를 들을 수 있는 인공 귀를 제작한 연구보고도 있다. ${ }^{24}$ 제작은 우선 silver nanoparticle이 포함된 하이드로겔 매트릭스를 $3 \mathrm{D}$ 프린터를 이용해 귀 모양으로 제작하고 이에 연골 세포를 심어준 다음 달팽이관 모양의 나선형 코일 주위에서 연골세 포를 배양하는 방식이었으며, 세포 배양을 통해 딱딱한 전자 장치를 연골조직이 감싸도록 하였다. 세포 배양 10 주 후에는 제작된 인공 귀가 소음에 반응하여 소리를 스피커로 전달하는 것을 확인하였다. 최근에는, 확대 비성형술(augmentation rhinoplasty)과 관련하여 3D 프린터를 활용한 동물실험 연구결 과도 있다. ${ }^{25)}$ 이는 $3 \mathrm{D}$ 프린터를 이용하여 융비를 위한 적절한 모양과 크기의 polycaprolactone 지지체를 만들고 이에 fibrin/chondrocytes 세포를 심어준 다음 토끼에 이를 삽입하 

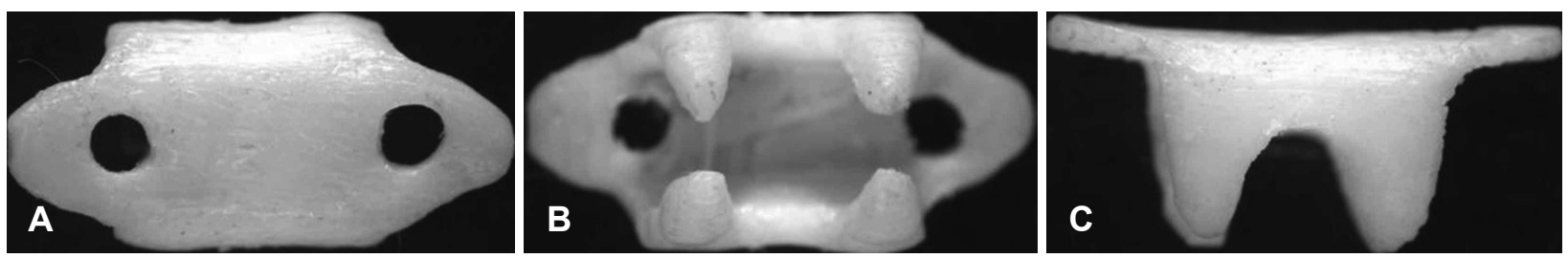

Fig. 1. Clip images fabricated by the 3D printer technology. Top view (A). Bottom view (B). Side view (C). 3D: three-dimensional.

여 확대 비성형술을 시행하였다. 확대 비성형술 12 주 후 평가 하였을 때, 이식물의 이동이나 탈출 등은 없었으며 우수한 생 체 적합성을 가짐을 보고하였다.

한편, 저자가 소속되어 있는 연구소에서도 $3 \mathrm{D}$ 프린터를 이 용하여 골절부위 고정을 위한 의료용 클립 시제품을 제작하 여 현재 동물실험 준비 중에 있다. 재료는 생체적합 폴리머인 polyactic acid를 이용하였고, 클립의 형태는 골절부위를 감 싸 쥐면서 고정시킬 수 있도록 제작하였다(Fig. 1). 진행될 동 물실험을 통해 성공적인 골절 치유가 관찰이 된다면, 향후 안 면골 골절 환자에서 환자 맞춤형으로 클립을 제작할 수 있어 기존의 제품화된 플레이트를 이용한 재건 방식보다 좋은 기능 적, 미용적 재건 결과를 얻을 수 있을 것으로 생각된다.

\section{결 론}

$3 \mathrm{D}$ 프린팅 기술은 제3차 산업혁명을 가져올 기술로 평가받 을 만큼 혁신적인 제조 방법이며, 조만간 특허의 만료로 인하 여 기존의 고가였던 일부 우수한 품질의 $3 \mathrm{D}$ 프린터 장비도 저렴한 가격으로 산업 전반에 보급될 것으로 예상된다. 게다 가, 맞춤형 제작과 의료비 절감이 화두인 의료 분야에서 $3 \mathrm{D}$ 프린터의 활용도는 급속도로 성장하게 될 것이다. 오늘날, 안 면 성형 및 재건 분야에서 $3 \mathrm{D}$ 프린터의 활용은 이제 임상에 적용하기 시작된 시점이지만, $3 \mathrm{D}$ 프린터의 잠재력을 고려할 때 향후 안면 성형 및 재건 분야에서 활용도는 무궁무진할 것이다. 따라서, 안면 성형 및 재건수술 분야에서 성공적인 $3 \mathrm{D}$ 프린터의 활용 및 접근을 위해서는 각각의 $3 \mathrm{D}$ 프린터의 특징 에 대한 정확한 이해를 바탕으로 이를 응용하여 여러 임상적 인 상황에 적용해 나가는 것이 필요하다.

\section{REFERENCES}

1) Michalski MH, Ross JS. The shape of things to come: $3 D$ printing in medicine. JAMA 2014;312(21):2213-4.

2) Lee $\mathrm{M}, \mathrm{Wu}$ BM. Recent advances in $3 \mathrm{D}$ printing of tissue engineering scaffolds. Methods Mol Biol 2012;868:257-67.

3) Maruthappu M, Keogh B. How might 3D printing affect clinical practice? BMJ 2014;349:g7709.

4) Zopf DA, Hollister SJ, Nelson ME, Ohye RG, Green GE. Bioresorbable airway splint created with a three-dimensional printer. N Engl J Med 2013;368(21):2043-5.

5) Tognola G, Parazzini M, Svelto C, Galli M, Ravazzani P, Grandori
F. Design of hearing aid shells by three dimensional laser scanning and mesh reconstruction. J Biomed Opt 2004;9(4):835-43.

6) Groth C, Kravitz ND, Jones PE, Graham JW, Redmond WR. Three-dimensional printing technology. J Clin Orthod 2014;48(8): 475-85.

7) Costello JP, Olivieri LJ, Krieger A, Thabit O, Marshall MB, Yoo SJ, et al. Utilizing Three-Dimensional Printing Technology to Assess the Feasibility of High-Fidelity Synthetic Ventricular Septal Defect Models for Simulation in Medical Education. World J Pediatr Congenit Heart Surg 2014;5(3):421-6.

8) Schmauss D, Schmitz C, Bigdeli AK, Weber S, Gerber N, BeirasFernandez A, et al. Three-dimensional printing of models for preoperative planning and simulation of transcatheter valve replacement. Ann Thorac Surg 2012;93(2):e31-3.

9) Omori S, Murase T, Oka K, Kawanishi Y, Oura K, Tanaka H. Postoperative accuracy analysis of three-dimensional corrective osteotomy for cubitus varus deformity with a custom-made surgical guide based on computer simulation. J Shoulder Elbow Surg 2015; 24(2):242-9.

10) Kurenov SN, Ionita C, Sammons D, Demmy TL. Three-dimensional printing to facilitate anatomic study, device development, simulation, and planning in thoracic surgery. J Thorac Cardiovasc Surg 2015; 149(4):973-9.e1.

11) Takagi K, Nanashima A, Abo T, Arai J, Matsuo N, Fukuda T, et al. Three-dimensional printing model of liver for operative simulation in perihilar cholangiocarcinoma. Hepatogastroenterology 2014; 61(136):2315-6.

12) Kang SH, Kim MK, Kim HJ, Zhengguo P, Lee SH. Accuracy assessment of image-based surface meshing for volumetric computed tomography images in the craniofacial region. J Craniofac Surg 2014; 25(6):2051-5.

13) Zhang X, Zhang Y. Tissue Engineering Applications of ThreeDimensional Bioprinting. Cell Biochem Biophys. 2015 Feb 7 [Epub]. http://dx.doi.org/10.1007/s12013-015-0531-x.

14) Dias AD, Kingsley DM, Corr DT. Recent advances in bioprinting and applications for biosensing. Biosensors (Basel) 2014;4(2):111-36.

15) Collins SF. Bioprinting is changing regenerative medicine forever. Stem Cells Dev 2014;23 Suppl 1:79-82.

16) Olszewski R, Szymor P, Kozakiewicz M. Accuracy of threedimensional, paper-based models generated using a low-cost, three-dimensional printer. J Craniomaxillofac Surg 2014;42(8): 1847-52.

17) Cohen A, Laviv A, Berman P, Nashef R, Abu-Tair J. Mandibular reconstruction using stereolithographic 3-dimensional printing modeling technology. Oral Surg Oral Med Oral Pathol Oral Radiol Endod 2009;108(5):661-6.

18) Azuma $M$, Yanagawa $T$, Ishibashi-Kanno $N$, Uchida $F$, Ito $T$, Yamagata $\mathrm{K}$, et al. Mandibular reconstruction using plates prebent to fit rapid prototyping 3-dimensional printing models ameliorates contour deformity. Head Face Med 2014;10:45.

19) Li B, Zhang L, Sun H, Yuan J, Shen SG, Wang X. A novel method of computer aided orthognathic surgery using individual CAD/CAM templates: a combination of osteotomy and repositioning guides. Br J Oral Maxillofac Surg 2013;51(8):e239-44. 
20) Li J, Hsu Y, Luo E, Khadka A, Hu J. Computer-aided design and manufacturing and rapid prototyped nanoscale hydroxyapatite/ polyamide (n-HA/PA) construction for condylar defect caused by mandibular angle ostectomy. Aesthetic Plast Surg 2011;35(4):636-40.

21) Wang G, Li J, Khadka A, Hsu Y, Li W, Hu J. CAD/CAM and rapid prototyped titanium for reconstruction of ramus defect and condylar fracture caused by mandibular reduction. Oral Surg Oral Med Oral Pathol Oral Radiol 2012;113(3):356-61.

22) Zhou LB, Shang HT, He LS, Bo B, Liu GC, Liu YP, et al. Accurate reconstruction of discontinuous mandible using a reverse engineering/ computer-aided design/rapid prototyping technique: a preliminary clinical study. J Oral Maxillofac Surg 2010;68(9):2115-21.

23) Xu H, Han D, Dong JS, Shen GX, Chai G, Yu ZY, et al. Rapid prototyped PGA/PLA scaffolds in the reconstruction of mandibular condyle bone defects. Int J Med Robot 2010;6(1):66-72.

24) Mannoor MS, Jiang Z, James T, Kong YL, Malatesta KA, Soboyejo WO, et al. 3D printed bionic ears. Nano Lett 2013;13(6):2634-9.

25) Kim YS, Shin YS, Park DY, Choi JW, Park JK, Kim DH, et al. The Application of Three-Dimensional Printing in Animal Model of Augmentation Rhinoplasty. Ann Biomed Eng. 2015 Jan 31 [Epub]. http://dx.doi.org/10.1007/s10439-015-1261-3.

\section{정답 및 해설}

답 (5)

해 설 그림은 구개융기(torus palatinus)로서 구개골 중앙부의 봉합부가 융기된 것을 말한다. 크기가 큰 경우 의치장착에 방해가 되는 수가 있으나 대부분 특별한 증상이 없다. 검사나 수술은 필요 없고, 환자를 안심시키면 된다. 